\title{
Geoscięnces
}

http://dx.doi.org/10.1590/0370-44672020740049

\author{
Luana Claudia Pereira ${ }^{1,2}$ \\ https://orcid.org/0000-0001-7275-984X \\ Douglas José Coêlho ${ }^{1,3}$ \\ https://orcid.org/0000-0003-4447-9300 \\ Archange Michael Ilambwetsi ${ }^{1,4}$ \\ https://orcid.org/0000-0001-5505-6085 \\ Tatiane Robaina R. de Carvalho ${ }^{1,5}$ \\ https://orcid.org/0000-0003-3561-0653 \\ Pablo de Azevedo Rocha ${ }^{1,6}$ \\ https://orcid.org/0000-0001-9581-9622 \\ Eduardo Antonio Gomes Marques ${ }^{1,7}$ \\ https://orcid.org/0000-0002-3476-8558 \\ ${ }^{1}$ Universidade Federal de Viçosa - UFV, Centro \\ de Ciências Exatas e Tecnológicas (CCE), \\ Departamento de Engenharia Civil, \\ Viçosa - Minas Gerais - Brasil. \\ E-mails: \\ 2luanac_pereira@hotmail.com, luanac.pereira@ufv.com \\ 롱ouglascoelho@outlook.com, ${ }^{4}$ i.archange2@gmail.com \\ tatianerrcarvalho@gmail.com, ${ }^{6}$ pab_zulu@yahoo.com.br \\ 7emarques@ufv.br
}

\section{Geological - geotechnical characterization of different lithotypes in an underground mine}

\begin{abstract}
A mineralogical, geological and geotechnical characterization of several rock types (phyllite, dolomite, breccia and marl) from an underground mine site aimed, among other things, to identify its mineral composition and to provide parameters to support the understanding of rock mass behavior. For this purpose, it was possible to perform laboratory and in situ tests or use existing empirical correlations. In this manuscript, the results of the following laboratory tests are presented and analysed - physical indices, point load test, Schmidt Hammer, uniaxial compression strength, wave propagation, micropetrographic description and X-ray diffraction. It was verified that the results obtained are consistent with other studies carried out in the region and also with results from the technical literature for similar lithotypes. Finally, the results contributed to improve the existing database on correlations among different trials.
\end{abstract}

Keywords: metamorphic rocks, carbonatic rocks, geological-geotechnical characterization.

\section{Introduction}

The geological-geotechnical characterization of rock materials is a procedure for the description and quantification of some of the conditions of a rock mass that control its behavior, in response to loads imposed by an engineering work or by nature itself (Charbel et al., 2016).

In underground excavations, the geological-geotechnical characterization is a procedure that allows to collect data used to evaluate the quality of the rock mass to be excavated. The planning and execution of these investigations must meet two basic requirements. The first one is to describe and quantify the conditions of the rock mass, related to the geotechnical problem under analysis. The second one is to give information whose quality and quantity satisfy the sophistication of the design methods, whether empirical, analytical or numerical, used in the planning and execution of the excavations (Serra and Ojima, 1998).

However, performing a geologicalgeotechnical characterization through laboratory tests is not a trivial task. As reported by Liu et al., (2017), laboratory and / or in situ tests have limitations associated with the anisotropy and heterogeneity of the rock mass, high costs, the required time, and in some cases, with the execution of some tests. So, considering these difficulties, Chang et al., (2006) argue that the use of empirical relationships is a frequent way in rock mechanics to estimate rock properties, and the basis for these relationships is that many of the factors that affect rock strength for example, also affect other properties, such as wave propagation velocity, elastic modulus and porosity, among others.

Furthermore, Hadjigeorgiou (2012) reinforced Hoek and Brown's proposition that data from laboratory tests are appropriate for inferring the strength of the intact rock rather than the rock mass because of the significant increase in resistance with decreasing sample size. Furthermore, rock mass parameters can be obtained using classification systems, such as RMR and GSI.

Thus, the aim of the present research was to perform laboratory tests to characterize the mineralogical, geo- 
mechanical and geotechnical properties of the metamorphic and sedimentary rocks - phyllites, dolomites, breccias and marls - of an underground mining located in southeast Brazil. Empirical correlations

\section{Methods}

The mine from which the samples were taken is an underground mine located in a shear zone, in which mineralized fluids percolated, generating the mineralization. The geological group is denominated Vazante Group and the context is characterized by intense deformations associated with variable metamorphism grades. The rock mass behavior at the mining site is controlled by its high geotechnical complexity, an expressive hydrogeological system (one of the highest dewatering systems within Brazil) and its karstic and structural characteristics (especially those structures with NW-SE direction). These characteristics provide an ideal scenario were also used to identify relationships among the different tests performed, in order to provide a reliable database for future use. The mine from which the samples were taken is an underground mine located in the state of Minas Gerais, southeast Brazil but more detailed information will not be provided, as the mining company did not allow disclosure of its geological location data. for rock mass failures, increase of alteration and karsification processes - cavity formations (Bhering, 2009; Bittencourt and Neto, 2012).

The mine that provided the samples operates on two different mining fronts, and rock samples were collected at both sites from drill cores with a diameter of $3.6 \mathrm{~cm}$, at different depths. The selection and collection of samples were mainly carried out by the mining company staff without information about the profundity, but samples from phyllite (FIL) and breccia (BXD) were collected by the authors, during a technical visit.

Mechanical strength tests and deformability tests were performed.
Specifically, the following tests and analyses were performed: determination of physical indices (dry and saturated apparent specific mass, effective porosity and apparent absorption capacity); Point Load Test (PLT); Schmidt Hammer; Uniaxial Compression Strength (UCS) with deformation measurements and longitudinal wave propagation velocity; petrographic thin section description and X-ray diffractometry (XRD). All lithotypes tested were fresh rocks and there were three samples that were in contact with two rocks. The different lithotypes tested are shown in Table 1 and the number of samples tested per lithotype is shown in Table 2.

Table 1 - Tested lithotypes.

\begin{tabular}{c|c|c|c}
\hline ID & Lithotype & MGA & Marl \\
\hline FIL & Phyllite & DCZ/MGA & Gray dolomite / Marl \\
\hline DCZ & Gray dolomite & DCZ/FIL & Gray dolomite / Phyllite \\
\hline BXD & Breccia & DCZ/DORO & Gray dolomite/Pink dolomite \\
\hline DORO & Pink dolomite & & \\
\hline
\end{tabular}

Table 2 -Types of tests performed and numbers of samples tested per lithotype.

\begin{tabular}{c|c|c|c|c|c|c|c}
\hline ID & Physical indices & PLT & Schmidt Hammer & UCS & Wave propagation velocity & Micropetrographic analyses & XRD \\
\hline FIL & 3 & 40 & 61 & 9 & 40 & 6 & 6 \\
\hline DCZ & 2 & 17 & 39 & 8 & 17 & 4 & 4 \\
\hline BXD & 3 & 28 & 59 & & 28 & 6 & 6 \\
\hline DORO & 1 & 10 & 24 & & 10 & 2 & 2 \\
\hline MGA & 1 & 13 & 20 & 8 & 13 & 2 & 2 \\
\hline DCZ/MGA & 1 & 8 & 19 & & 8 & 2 & 2 \\
\hline DCZ/FIL & 1 & 5 & 19 & & 5 & 2 & 2 \\
\hline DCZ/DORO & 1 & 5 & 20 & & 5 & & 2 \\
\hline
\end{tabular}

The results of the physical indices can be used to quantitatively characterize the intact rock and to correlate with its mechanical properties. Among these, the apparent (effective) porosity, dry and saturated apparent specific mass, and apparent absorption capacity were determined in the present study. On the other hand, the tests of strength and deformability were performed in order to infer the mechanical behavior of the rock matrix. For this, some tests were carried out, such as the Schmidt Hammer, the PLT, the uniaxial compression strength and the longitudinal wave propagation velocity.

The Schmidt Hammer Q values were firstly corrected by the constant factor of the Schmidt Hammer used in this research. After that, the digital $Q$ value was corrected to determine the $R$ value, by using the correction proposed by Winkler and Mathews (2014). Finally, the UCS was obtained by using the dry specific mass and the Deere and Miller (1966) equation. The type of Schmidt Hammer used was L.

The Point Load Test was performed mostly on diametral and irregular samples of FIL and BXD. PLT tests were not performed considering the perpendicular and parallel directions of the rocks. In the present study, two specimens of each three lithotypes were tested to determine the expected failure 
load. Values equal to 140,230 and $150 \mathrm{KN}$ were obtained for the FIL, DCZ and MGA, respectively. Subsequently, these values were used in a uniaxial compression test, in which three loading and unloading cycles were

$\sigma_{c 50}$ the tension for the test piece with a diameter of $50 \mathrm{~mm}$; $\sigma_{c}$ the tension obtained in the test; $d$ is the diameter of the $\mathrm{CP}$ tested.

The uniaxial compression strength test is an assay that can provide information on both strength and deformation. A longitudinal wave propagation test was also carried out and consists of a nondestructive test that provides information

$U C S(\mathrm{MPa}) ; V_{p}(\mathrm{Km} / \mathrm{s})$ and $E(\mathrm{GPa})$

UCS is the uniaxial compression strength $V_{p}$ is the velocity of wave propagation $E$ is the modulus of elasticity

The Schmidt Hammer test was performed for several samples, varying according to their availability; 9 samples of FIL, 8 of DCZ and 8 of MGA were tested for uniaxial compression strength (Table 2 ), with two samples of each lithotype being tested previously to determine the

\section{Results and discussion}

The results of the tests are presented in the order they were performed. The physical indices showed that all rock samples tested have presented low porosity values. FIL and BXD samples from the rock blocks collected at the mine site presented high effective (apparent) porosity values $(334 \%$ and $209 \%$ increase, respectively) when compared to the samples colleted from boreholes for the same lithotypes, and their results were discarded as this difference could have been caused by detonation. It should be noted that the values obtained for these samples for the specific mass, dry and saturated, and for the absorption capacity were also discarded. In general, it was observed that for materials composed by two combined rock types, such as DCZ/MGA, DCZ/FIL used, one at $40 \%$, the second at $50 \%$ and the last at $60 \%$ of the expected failure load obtained in the initial tests. After the three cycles, the longitudinal extensometer used to collect data during the test was removed and the specimen

$$
\sigma_{c 50}=\sigma_{c}\left(\frac{50}{d}\right)^{0.18}
$$

on the elastic characteristics and on the fracturing of rock samples.

All the tests were performed according to the standards suggested by ISRM (2007). For PLT, the following quantities of samples were tested: 40 of FIL (in two different directions in relation to foliation in order to verify anisotropy effects), 17 of DCZ, 28 of BXD, 5 of DCZ/DORO, 10 of DORO, 13 of MGA, 8 of DCZ/MGA

$$
\begin{gathered}
\text { UCS }=9.95 * V_{p}^{1.21} \\
\text { UCS }=\left(31.5 * V_{p}\right)-63.7 \\
E=\left(10.67 * V_{p}\right)-18.71
\end{gathered}
$$

and 5 of DCZ/FIL. In all of these samples, the wave propagation velocity test was performed prior to the PLT test.

Brisevac et al., (2016) presented a compilation of simple regression equations that correlate wave propagation velocity with uniaxial compression strength and modulus of elasticity. Among these equations, there are two that contemplate dolomites, Equations 2, 3 and 4.

predicted breaking load, whose value was used as reference to test the other samples.

The mineralogical characterization was performed in order to obtain the maximum information about the intact rock characteristics, including the identification of its minerals. Six petrographic slides of FIL, 4 of DCZ, 6 of BXD, and 2 of DORO, MGA, DCZ/ MGA, DCZ/FIL and DCZ/DORO were prepared (Table 2). The preparation of

and DCZ/DORO, a reduction in porosity is observed for these latter ones when compared to the "pure" rock type. So, porosity measeured for FIL and DCZ are higher than the one measured for DCZ/FIL samples and the same can be seen for DCZ/MGA samples.

In this study, all Schmidt Hammer measurements $(\mathrm{Q})$ were performed perpendicular to the folitaion. The results obtained are presented in Table 3 . It is noted that the lowest values were obtained for FIL, DCZ and BXD, and the highest for DCZ/FIL, MGA and DORO. High standard deviation values (higher than $10 \%$ ) were found for all rock types, exception being $D C Z / D O R O$. In general, $R$ values are very similar for all carbonatic rocks (the exception being grey dolomite), while phyllite and breccia present lower values.

Schaefer et al., (2015) argues that porosity can control mechanical responses of rocks given by decreased strength and increased deformability. However, correlating the apparent porosity with the mean strength, it is noted that for the tested lithotypes, it was not possible to verify this observation. It should be noted, however, that the porosities presented very low values, between $0.5 \%$ and $1.5 \%$. In these cases, usually, the presence of geological "defects", such as foliation, imbrication among grains, grain size, microfracturing, among others, has a much more important effect on strength and deformability than variations in porosity. 
Table 3- Results of Schmidt Hammer.

\begin{tabular}{|c|c|c|c|c|c|}
\hline ID & Mean Q Value & Standard deviation & Corrected Q Value* & R Value (Winkler \& Matthews, 2014) & UCS (MPa) \\
\hline FIL & 37.9 & 15.3 & 35.2 & 26.6 & 45.5 \\
\hline DCZ & 37.2 & 9.9 & 34.6 & 26.0 & 36.4 \\
\hline BXD & 38.6 & 12.3 & 35.9 & 27.3 & 47.7 \\
\hline DORO & 49.8 & 7.4 & 46.3 & 37.8 & 88.4 \\
\hline MGA & 52.0 & 8.8 & 48.4 & 39.8 & 97.0 \\
\hline DCZ/MGA & 49.9 & 4.6 & 46.4 & 37.8 & 85.4 \\
\hline DCZ/FIL & 52.7 & 7.3 & 49.0 & 40.4 & 100.4 \\
\hline DCZ/DORO & 41.7 & 2.7 & 38.8 & 30.2 & 58.1 \\
\hline
\end{tabular}

* Value corrected by the equipment costant, equal to 0.93 .

The results of PLT are presented in Table 4, which also shows the total number of samples tested, the number of samples with valid breaks, according to the ISRM (2007), and the number of samples used to calculate the mean. Anisotropy was not considered for PLT. The highest values of the mean $\mathrm{Is}_{50}$ were ob- tained for dolomites (DCZ and DORO), and the lowest value was obtained for DCZ/MGA. The DORO's data were the most homogeneous and those from the BXD the most dispersed. Leão (2017) analyzing phyllites with different degrees of alteration in the region of Ouro Preto / Minas Gerais State found mean Is ${ }_{50}$ values ranging from 0.2 to 1.15

Andrade and Saraiva (2010) reported values between 0.6 and $3.9 \mathrm{MPa}$ for $\mathrm{Is}_{50}$ of phyllites in the central region of Portugal. The phyllite samples analyzed in the present study presented values slightly higher than those obtained by these authors.

Table 4 - Results of point load test

\begin{tabular}{c|c|c|c|c}
\hline ID & Number of total samples & Number of samples with valid rupture & $\begin{array}{c}\text { Mean Is } \\
(\mathbf{M P a})\end{array}$ & $\begin{array}{c}\text { Standard Deviation Is } \\
(\mathbf{M P a})\end{array}$ \\
\hline FIL & 40 & 30 & 4.38 & 2.01 \\
\hline DCZ & 17 & 17 & 9.65 & 1.76 \\
\hline BXD & 28 & 28 & 7.94 & 3.55 \\
\hline DORO & 10 & 10 & 9.66 & 0.61 \\
\hline MGA & 13 & 13 & 5.25 & 2.22 \\
\hline DCZ/MGA & 8 & 8 & 4.10 & 1.65 \\
\hline DCZ/FIL & 5 & 5 & 4.79 & 3.18 \\
\hline DCZ/DORO & 5 & 4 & 2.53 & 3.06 \\
\hline
\end{tabular}

The $\mathrm{Is}_{50}$ can be correlated with the uniaxial compression strength through empirical equations. Several authors defend a linear correlation in which the value of the index is multiplied by a fixed correlation factor. Goodman (1989) argues that the correction factor is equal to 24 . Barroso (1993) and Foster (1983) state that the factor consists of an interval ranging from 18 to 24 and 10 to 50, respectively. Leão (2017) mentions studies in which the linear relationship between Is $_{50}$ and UCS is five times.

Kahraman et al., (2005) obtained correction factor values equal to 18.2 for igneous and sedimentary rocks, and 16.6 for metamorphic rocks. Some authors, such as Azimian et al., (2014) and Kiliç and Teymen (2008), found logarithmic relationships between the $\mathrm{Is}_{50}$ and the uniaxial compression strength for different types of rocks, with different degrees of change. Based on the results presented in Table 3 and in Table 4, the correclation factor varies from 3.8 and 23.2, with values differente from the ranges proposed by Barroso (1993) and Foster (1983).

Brisevac et al., (2016) argue that the uniaxial compressive strength and modulus of elasticity can be determined in a simple or complex way, excluding the more recommended procedure, via laboratory tests. The simple way is to query existing tables and diagrams or use simple regression equations. The complex approach encompasses multiple regression equations, fuzzy logic models, artificial neural networks, evolutionary progression models, and regression tree models. These authors mention that these resources can be used in the initial stages of project or for verification/validation of laboratory results.

Among the results obtained for the
FIL (Table 5), it was found that the lowest value obtained was 91.17 and was related to a sample that had cracks before the test and, consequently, the value obtained in the test was very low and different from the others. A second outstanding result was one performed in the oblique direction of the discontinuities, resulting in a UCS equal to $245.71 \mathrm{MPa}$. The phyllites showed an anisotropic force behavior, since the UCS for the direction parallel to the foliation is greater than that of the oblique direction. On the other hand, the modulus of elasticity is isotropic.

From the analysis of Table 5, it can be noticed that DCZ can present a differentiated behavior, related to the presence of carbonate veins that decreased the UCS strength by half, since the veins develop along a discontinuity surface. The values obtained for the DCZ for both the strength 
and the elasticity modulus differ from those found by Charbel (2015), for dolomites, $124 \mathrm{MPa}$ and $58 \mathrm{GPa}$, respectively. Bhering (2009) has obtained a strength value, $324 \mathrm{MPa}$, very similar to that obtained for DCZ without the presence of carbonate veins. All the results obtained for the MGA were similar to each other, and in agreement with Bhering (2009), which was equal to $113.52 \mathrm{MPa}$.

Comparing the results obtained in the present study with those presented by Yasar and Erdogan (2004) for dolomites and marls, it can be seen that the values differ between them, being the ones of those authors lower than the ones observed for DCZ and MGA.

Table 5 - Results of strength and deformability.

\begin{tabular}{|c|c|c|c|c|c|c|}
\hline ID & $\begin{array}{l}\text { Uniaxial Strength } \\
(\mathrm{MPa})\end{array}$ & $\begin{array}{c}\text { Uniaxial Strength for } \\
50 \mathrm{~mm} \text { diameter } \\
(\mathrm{MPa})\end{array}$ & $\begin{array}{c}\text { Mean UCS } \\
(\mathrm{MPa})\end{array}$ & $\begin{array}{c}\text { Standard } \\
\text { deviation of UCS } \\
(\mathrm{MPa})\end{array}$ & $\begin{array}{c}\text { Elastic Module } \\
\text { (GPa) }\end{array}$ & $\begin{array}{c}\text { Mean Elastic } \\
\text { Module } \\
(\mathrm{GPa}) \\
\end{array}$ \\
\hline \multirow{3}{*}{ FIL (Oblique) } & 237.01 & 251.45 & \multirow{3}{*}{270.68} & \multirow{3}{*}{25.74} & 133.5 & \multirow{3}{*}{126.5} \\
\hline & 245.71 & 260.67 & & & 117.7 & \\
\hline & 282.70 & 299.92 & & & 128.2 & \\
\hline \multirow{4}{*}{ FIL (Parallel) } & 104.49 & 110.86 & \multirow{4}{*}{123.30} & \multirow{4}{*}{29.50} & 80.2 & \multirow{4}{*}{126.3} \\
\hline & 155.64 & 165.12 & & & 228.9 & \\
\hline & 91.17 & 96.72 & & & 105.3 & \\
\hline & 113.75 & 120.67 & & & 91.0 & \\
\hline \multirow{2}{*}{ DCZ } & 357.24 & 379.00 & \multirow{2}{*}{353.56} & \multirow{2}{*}{35.99} & 171.1 & \multirow{2}{*}{170.61} \\
\hline & 309.27 & 328.11 & & & 170.1 & \\
\hline \multirow{2}{*}{ DCZ (vein) } & 153.01 & 162.33 & \multirow{2}{*}{181.85} & \multirow{2}{*}{27.59} & 136.8 & \multirow{2}{*}{156.23} \\
\hline & 189.80 & 201.36 & & & 175.7 & \\
\hline \multirow{4}{*}{ MGA } & 129.90 & 137.81 & \multirow{4}{*}{119.87} & \multirow{4}{*}{14.49} & 79.5 & \multirow{4}{*}{76.56} \\
\hline & 109.19 & 115.84 & & & 72.0 & \\
\hline & 97.11 & 103.03 & & & 82.3 & \\
\hline & 115.74 & 122.79 & & & 72.4 & \\
\hline
\end{tabular}

Table 6 shows a comparison between the values obtained by the uniaxial compression strength test with the PLT values for the FIL, DCZ and MGA lithotypes. The correlation factor between UCS and $\mathrm{Is}_{50}$ are also higher and are in line with the range proposed by Foster (1983). Only MGA presented a correction factor close to that value suggested by Goodman (1989), thus indicating that, for these lithotypes, the PLT provides a reasonable estimate of their uniaxial strengths. However, for the other lithotypes, the correction factor must be specific for each one and not generalized, as proposed by Goodman (1989) and the use of a range is more acceptable.

Table 6 - Comparison between the mean UCS obtained from the uniaxial compressive test and the mean $\mathrm{IS}_{50}$.

\begin{tabular}{c|c|c|c}
\hline ID & Mean UCS $(\mathrm{MPa})$ & Mean Is $_{\mathbf{5 0}}(\mathrm{MPa})$ & Correlation factor \\
\hline FIL (Oblique) & 275.7 & N.D. & N.D. \\
\hline FIL (Parallel) & 132.2 & 4.4 & 30 \\
\hline DCZ & 353.6 & 9.7 & 36 \\
\hline DCZ (vein) & 181.9 & N.D. & N.D. \\
\hline MGA & 119.9 & 5.3 & 23 \\
\hline
\end{tabular}

N.D.- Not determined.

When comparing the results from UCS tests to the ones obtained from Schmidt Hammer tests, Table 7, UCS values are much higher for FIL (oblique) and for DCZ and much higher than the ones from Schmidt Hammer. For MGA, on the other hand, values from UCS and Schmidt Hammer were closer.

Nogueira (2000) obtained, for two types of different phyllites, sericitic and dolomitic, from the region of Quadrilátero Ferrífero, values of UCS strength in a range between 10.4 to $33.7 \mathrm{MPa}$ and 100.0 to $294.8 \mathrm{MPa}$, respectively. Andrade and Saraiva (2010), studying physical and mechanical characteristics of phyllites in the central region of Portugal, has obtained UCS strength values between 24.0 and 52.2 MPa. However, Quinta-Ferreira et al., (2015), study- ing a phyllite also in Portugal, found that an average UCS strength equal to 38.9 MPa. It can be observed that the FIL presented values consistent with the ranges of both the resistance and the deformability of the dolomitic phyllite studied by Nogueira (2000).

A study of carbonate rocks from a gas field in Iran using computed tomography images, carried out by Mehrgini et 
al., (2016) have found the following mean values of uniaxial compression strength and modulus of elasticity for two types of dolomite, respectively, 148 and $22 \mathrm{MPa}$ and 59 and $8.4 \mathrm{GPa}$. Ilambwetsi et al.,
(2020) obtained excellent correlations between the uniaxial compressive strength and $\mathrm{Is}_{50}$ for three types of carbonate rocks (calcarenite, calcilutite, and marble) of the Sete Lagoas Formation, southeast
Brazil, which are not recognized in scientific literature. The values obtained for dolomites in the present study were higher, showing better mechanical behavior for these rock matrices.

Table 7 - Comparison between the UCS obtained from the uniaxial compressive strength and from the Schmidt Hammer test.

\begin{tabular}{c|c|c}
\hline ID & Average UCS from UCS tests (MPa) & Average UCS from Schmidt Hammer tests (CS) \\
\hline FIL (Oblique) & 275.7 & N.D. \\
\hline FIL (Parallel) & 132.2 & 45.5 \\
\hline DCZ & 353.6 & 36.4 \\
\hline DCZ (vein) & 181.9 & N.D. \\
\hline MGA & 119.9 & 97.0 \\
\hline
\end{tabular}

N.D.- Not determined.

During the uniaxial compression strength test, the longitudinal deformation suffered by the specimens was measured, the elastic modulus was calculated according to ISRM (2007), and the results are presented in Table 5. All elasticity modulus was calculated on the loading curve of a load and discharge cycle corresponding to approximately $50 \%$ of the actual rupture load value.

For FIL samples it is shown that half of the tensile versus strain graphs obtained from the data from the test specimens showed the three cycles of loading and unloading with approximately the same inclination. The lower value of the elasticity modulus was observed for the sample that also presented the lower strength. DCZ samples also have shown tensile versus strain graphs with the loading and unloading cycles at approximately the same slope and all samples presented values of similar modulus of elasticity, except one, whose value was slightly lower. For the MGA samples, it can be seen that the values obtained for the modulus of elasticity were also very similar for all samples and no variation of the slope of the loading and unloading cycles was observed.

Bhering (2009) obtained mean tangential and secant deformability modulus values for the DCZ from the same region, respectively equal to 112 and $111 \mathrm{GPa}$, and carried out loading and unloading tests similar to the one performed in the present study. Comparing these results of the present study with those from Bhering (2009), there can be noted a 50\% difference among the results. Nogueira (2000) obtained, for two types of different phyllites, sericitic and dolomitic, from the region of Quadrilátero Ferrífero, values for the elasticity modulus that varied from
5.1 to 9.7 GPa for the sericitic phyllite and 60.0 to 383.3 for the dolomitic. Santi et al., (2000) presented a compilation of the tangential modulus of elasticity for several types of rock, among which there were three types of dolomite, and the resulting values for this parameter varied between 44.0 and $66.0 \mathrm{GPa}$, calculated at $50 \%$ of the maximum rupture stress. The values obtained for the DCZ in the present study are significantly higher than the values presented by these authors.

The longitudinal wave propagation test shown in Table 8 shows that the highest values were obtained for the dolomite samples, DORO, DCZ and DCZ / DORO, respectively. The lowest value was observed for DCZ / FIL. In addition, it is noted that the standard deviation value was presented by the phyllite sample. Nogueira (2000) obtained for two types of phyllites, sericitic and dolomitic, from the region of Quadrilátero Ferrífero, values of longitudinal wave speed from 2484 to $4122 \mathrm{~m} / \mathrm{s}$ and 4806 to $6753 \mathrm{~m} / \mathrm{s}$, respectively. Andrade and Saraiva (2010), have obtained values between 1530 and 5323 m/s. Quinta-Ferreira et al., (2015), in a study of a phyllite in Vila Velha de Rodão, also in Portugal, obtained a mean wave propagation velocity of $1657 \mathrm{~m} / \mathrm{s}$. The results found for the phyllite samples obtained in the present study are consistent with the values found by Andrade and Saraiva (2010). Stan-Kleczek (2016) carried out a comparative study focusing on the deformability parameters based on wave velocity from laboratory and field (refractive seismic) tests for two dolomite deposits in Poland. The values of the mean wave propagation velocity for the laboratory tests varied from 4791 to $5224 \mathrm{~m} / \mathrm{s}$. Comparing these values with those obtained for the studied dolomite samples, it is known that the velocity of wave propagation is higher and the dynamic modulus is lower for the rocks used in the present study.

Using equations presented by Brisevac et al., (2016) to determine the compressive strength as the modulus of elasticity of the DCZ, it was observed that the values for both the resistance and for the deformability were lower than those obtained in the laboratory test for the gray dolomite, with and without vein.

Mineralogical analyses were carried out using petrographic slides and X-ray diffraction. The preparation and interpretation of the petrographic slides allowed the identification of the minerals present in the samples of the different lithotypes, as well as the collection of information on the structures and textures of the same. The determination of the percentage of each mineral identified (modal analysis) was impaired, since the samples presented a very fine matrix, making it difficult to quantify the mineral content.

The presence of an opaque matrix with translucent calcite grains, silica and carbonate veins was observed in the FIL slides. For DCZ and MGA, the presence of a fine carbonaceous matrix, mudstone type, with presence of crystals of dolomitization maclas and feldspar grains was noted. Also, occurrences of carbonaceous veins and stylolites were observed, and in some veins, it was possible to visualize the presence of iron oxides. For the BXD, a thin carbonate matrix was observed with dolomitization maclas and veins filled with opaque minerals and carbonate, and sometimes also filled with iron oxides. For DORO, it was found that it has an essentially carbonate structure, 
composed of a fine matrix. It has the presence of fractures filled by carbonates or opaque minerals and some may not have been yet filled. DCZ/MGA presents two distinct matrices, one, clayey rich in sericite of dark gray color, and the other of brown color, such as a mudstone, but both are of carbonate constitution. The presence of fractures with and without filling was also observed. DCZ/FIL shows a fine carbonaceous matrix, from gray to light greenish, mainly composed by sericite. Calcite grains and opaque minerals are dispersed in matrix. Finally, DCZ/ DORO can be defined as a calcarenite composed of calcite and opaque minerals; with carbonate-filled fractures and others, unfilled.

The X-ray diffraction (XRD) allowed the qualitative determination of the minerals present in the analyzed samples. For FIL, chlorite, illite, mica, kaolinite, quartz and feldspar were identified. However, in one of the analyzed samples, the chlorite peak appeared in a discrete manner, indicating the possibility of prior treatment of the samples before the analysis. For DCZ, the presence of interstratified chlorite-smectite clay minerals, chlorite, ilite, and quartz was observed. It was not possible to identify the exact composition of the interstratified clay minerals, but it is probably chlorite.

Comparing the XRD results with those from the petrographic slides, both for FIL and DCZ, a similar mineralogy can be observed, the exception being the iron oxides and feldspars observed for the DCZ in the slides that did not appear in the diffractograms. For BXD, the presence of chlorite with interstratification, ilite/mica, kaolinite, chlorite and carbonates could be defined. The large number of carbonates impaired the interpretation of clay minerals. For DORO, the presence of carbonates and illite/mica was evident on the heated sample; however, in the natural and saturated condition, clay minerals were not cearly visible. For MGA, chlorite, mica, kaolinite, quartz and feldspar were identified. When comparing the XRD results with the ones from the petrographic slides, for BXD, DORO and MGA, it is noted that the large amount of carbonate observed on the XRD graphs was also identified in the slides. For DCZ/ MGA and DCZ/FIL, the same minerals were found, namely chlorite, mica/ilite, kaolinite, quartz and feldspar. For DCZ/ DORO, the presence of chlorite-smectite, chlorite, ilite/mica, kaolinite and quartz interstrates was observed. For this lithotype, once again, the large number of carbonates impaired the interpretation of clay minerals. The results of these three lithotypes are also consistent with the petrographic slides. Some of the minerals found for MGA, DCZ, DORO and BXD are consistent with those observed by Neves (2011). This author studied rocks from the same region.

Table 8 - Results obtained for the wave propagation test.

\begin{tabular}{c|c|c|c}
\hline ID & Number of samples & Average speed $(\mathbf{m} / \mathbf{s})$ & Standard deviation $(\mathbf{m} / \mathbf{s})$ \\
\hline FIL & 26 & 5261.7 & 825.0 \\
\hline DCZ & 16 & 6442.5 & 242.9 \\
\hline BXD & 22 & 6220.3 & 379.8 \\
\hline DORO & 11 & 6688.9 & 208.2 \\
\hline MGA & 12 & 5273.3 & 210.1 \\
\hline DCZ/MGA & 8 & 5360.9 & 676.7 \\
\hline DCZ/FIL & 5 & 5106.80 & 529.74 \\
\hline DCZ/DORO & 4 & 6383.75 & 336.31 \\
\hline
\end{tabular}

\section{Conclusions}

A general physical and mechanical characterization was performed for several carbonatic and phyllites from southeast Brazil. Rocks under study have presented a very low effective porosity and high saturated and dry apparent specific masses. Uniaxial compressive strength was performed from uniaxial compressive strength (UCS), Point Load ( $\mathrm{Is}_{50}$ ), Schmidt Hammer tests and wave propagation test. Results from UCS were, in general, considerably higher than the ones from Schmidt Hammer tests. Comparison between UCS and $\mathrm{Is}_{50}$ resulted in a cor- relation value in line with the range found in literature. Mineralogical analyses have shown that the most important mineral groups present in the rocks under study are carbonates with clay minerals, such as illite, chlorite, kaolinite, and interestratified chlorite-smectite.

\section{References}

ANDRADE, P. S.; SARAIVA, A. A. Physical and mechanical characterization of phyllites and metagreywackes in central Portugal. Bulletin of Engineering Geology Environment, v.69, p. 207-214, 2010.

AZIMIAN, A.; AJALLOEIAN, R.; FATEHI, L. An empirical correlation of uniaxial compressive strength with P-wave velocity and point load strength index on Marly rocks using statistical method. Geotechnical and Geological Engineering, v. 32, p. 205-214, 2014.

BARROSO, E. V. Estudo das características geológicas e do comportamento geotécnico de um perfil de intemperismo em leptinito. 1993. 251 f. Dissertação (Mestrado em Geologia) - Universidade Federal do Rio de Janeiro, Rio de Janeiro, 1993.

BHERING, A. P. Classificação do maciço rochoso e caracterização das brechas da mina subterrânea de Vazante - MG. 2009. 185 f. Dissertação (Mestrado em Engenharia Civil) - Universidade Federal de Viçosa, Viçosa, 2009. 
BITTENCOURT, C.; REIS NETO, J. M. O Sistema cárstico de Vazante: carste em profundidade em metadolomitos do grupo Vazante - MG. Revista Brasileira de Geociências, v. 42, n.1, p.1-10, 2012.

BRISEVAC, Z.; HRZENJAK, P.; BUJAN, R. Models for estimating uniaxial compressive strength and elastic modulus. Gradevinar, v. 68, p.19-28, 2016.

CHANG, C.; ZOBACK, M. D., KHAKSAR, A. Empirical relations between rock strength and physical properties in sedimentary rocks. Journal of Petroleum Science \& Engineering, v. 51, p. 223-237, 2006.

CHARBEL, P. A. Gerenciamento de risco aplicado à diluição de minério. 2015. 406 f. Tese (Doutorado em Geotecnia) - Departamento de Engenharia Civil e Ambiental, Faculdade de Tecnologia, Universidade de Brasília, Brasília, 2015.

CHARBEL, P. A.; CARVAJAL, H. E. M.; FARIAS, M. M.; ASSIS, A. P. Caracterização geológico-geotécnica da mina subetrrânea de Vazante. In: SIMPÓSIO BRASILEIRO DE MECÂNICA DAS ROCHAS, 7., 2016, Belo Horizonte. Anais [...]. Belo Horizonte: SBMR, 2016.

DEERE, D. U.; MILLER, R. P. Engineering classification and index properties for intact rock. Kirkland, New Mexico: US Air Force Weapons Lab, 1966. (Report AFWL-TR-65-16).

FOSTER, I. R. The influence of core sample geometry in the axial point load test. International Journal of Rock Mechanics and Mining Sciences, v. 20, p. 289-295, 1983.

GOODMAN, R. E. Introduction to rock mechanics. New York: John Wiley \& Sons, 1989, 562 p.

HADJIGEORGIOU, J. Where do the data come from? Mining Technology, v.121, n. 4, p. 236-247, 2012.

ILAMBWETSI, A. M.; GOMES, E. A. G.; LEÃO, M. F. Geomechanical characterization of carbonates of the Sete Lagoas Formation (Bambuí Group). REM - International Engineering Journal, v. 73, n.1, p. 17-22, 2020.

KAHRAMAN, S.; GUNAYDIN, O.; FENER, M. The effect of porosity on the relation between uniaxial compressive strength and point load index. International Journal of Rock Mechanics and Mining Sciences, v.42, p. 584-589, 2005.

KILIÇ, A.; TEYMEN, A. Determination of mechanical properties of rocks using simple methods. Bulletin of Engineering Geology and the Environment, v. 67, p. 237-244, 2008.

LEÃO, M. F. Comportamento geomecânico de frente de intemperismo em filito da região do Quadrilátero Ferrífero. 2017. 186 f. Tese (Doutorado em geologia) - Universidade Federal do Rio de Janeiro, Rio de Janeiro, 2017.

LIU, J.; SUN S.; YUE, L.; WEI, J.; WU, J. Mechanical and failure characteristics of rock-like material with multiple crossed joint sets under uniaxial compression. Advances in Mechanical Engineering, v. 9, p.1-18, 2017.

MEHRGINI, B. et al. Geomechanical characterization of a south Iran carbonate reservoir rock at ambient and reservoir temperatures. Journal of Natural Gas Science and Engineering, v. 34, p. 269-279, 2016.

NEVES, L. P. Características descritivas e genéticas do depósito de Zn-Pb Morro Agudo, Grupo Vazante. 2011. 186 f. Dissertação (Mestrado em Geologia) - Instituto de Geociências, Universidade de Brasília, Brasília, 2011.

NOGUEIRA, J. A. Propriedades mecânicas da rocha intacta na mineração de ferro. 2000. 106 f. Dissertação (Mestrado em Engenharia Metalúrgica e de Minas) - Escola de Engenharia, Universidade Federal de Minas Gerais, Belo Horizonte, 2000.

QUINTA-FERREIRA, M. et al. Geologia de Engenharia de rochas xistosas: os xistos negros da EN17 em Coimbra e os filitos de Vila Velha de Ródão. Comunicações Geológicas, v. 102, p. 83-90, 2015.

SANTI, P.; HOLSCHEN, J. E.; STEPHENSON, R. W. Improving elastic modulus measurements for rock based on geology. Environmental and Engineering Geoscience, v. 6, n.4, p. 333-346, 2000.

SCHAEFER, L.; KENDRICK, J.; OOMMEN, T.; LAVALLÉE, Y.; CHIGNA, G. Geomechanical rock properties of a basaltic volcano. Frontiers in Earth Science, v. 3, p. 1-15, 2015.

SERRA, E. J.; OJIMA, L. M. Caracterização e classificação de maciços rochosos. In: SANTOS, A. M.; BRITO, S. N. A. (ed.). Geologia de engenharia. São Paulo: ABGE, 1998. cap. 13, p. 211-226.

STAN-KLECZEK, I. The study of the elastic prooperties of carbonate rocks on a base of laboratory and field measurement. Acta Montanistica Slovaca, v. 21, p.76-83, 2016.

ULUSAY, R.; HUDSON, J. A. (ed.). The complete ISRM suggested methods for characterization, testing and monitoring: 1974-2006. Ankara, Turkey: ISRM - International Society of Rock Mechanics, 2007. 628 p.

WINKLER, S.; MATTEWS, J. A. Comparison of electronic and mechanical Schmidt hammers in the context of exposure-age dating: are Q- and R-values interconvertible? Earth Surface Processes and Landforms, v. 39, n.8, 2014. DOI 10.1002/esp.3584.

YASAR, E.; ERDOGAN, Y. Correlating sound velocity with the density, compressive strength and Young's modulus of carbonate rocks. International Journal of Rock Mechanics and Mining Sciences, v. 41, n. 5, p.871-875, 2004.

Received: 20 April 2020 - Accepted: 20 October 2020. 